\title{
Access to Rural Credit Markets in Developing Countries, the Case of Vietnam: A Literature Review
}

\author{
Ta Nhat Linh ${ }^{1,2, *}$, Hoang Thanh Long ${ }^{3}$, Le Van Chi ${ }^{1}$, Le Thanh Tam ${ }^{1}$ and Philippe Lebailly ${ }^{2}$ \\ 1 School of Banking and Finance, National Economics University, Hanoi 100000, Vietnam; \\ vanchi.le88@gmail.com (L.V.C.); taminhanoi@gmail.com (L.T.T.) \\ 2 Economics \& Rural Development, Gembloux Agro-Bio Tech, University of Liege, 5030 Gembloux, Belgium; \\ philippe.lebailly@uliege.be \\ 3 Faculty of Economic Information Systems, University of Economics, Hue University, Hue 530000, Vietnam; \\ hoangthanhlong@hce.edu.vn \\ * Correspondence: tanhatlinh@gmail.com
}

Received: 28 December 2018; Accepted: 4 March 2019; Published: 9 March 2019

\begin{abstract}
Agricultural sectors play an important role in the process of economic development of a country, especially in developing ones. Vietnam is known as an emerging market, which depends directly on agriculture-related activities for their livelihood, in which the issue of rural credit access still remains a confounding problem. The paper focuses on the characteristics of rural credit markets, the determinants of farmer access to the markets, the socio-economic impacts of credit access in Vietnam and briefly comparing with those of some developing countries. This question is addressed by reviewing existing literature and empirical evidence, followed by a comprehensive case study in Vietnam. Comprehensive literature review with secondary data collection and key informant interviews are methods that are applied in this research. The results of this analysis indicate the features of Vietnam markets as participated constraints, government intervention, and segmentation. Other results reveal the significant determinants of credit accessibility. Impacts of credit access on output production, household income, and poverty reduction are highlighted in this paper. Some managerial implications are recommended for households through participation in lending networks; for financial institutions relating to expand target clients as well as capital allocation; and, for policy-makers via ensuring market competitiveness and sustainable development in the long run.
\end{abstract}

Keywords: agriculture credit; rural credit accessibility; credit constraints; emerging nations

\section{Introduction}

Agriculture has been considered as one of the most economic sectors of all economies, especially in developing nations. The agriculture sector is crucial to not only internal food security, but also employment growth and poverty reduction [1]. Agriculture is now considered as an economic sector, not only in rural areas, but also in urban ones [2-4]. Additionally, agricultural production in rural area still accounts for a large proportion, contributing to the employment of the majority of workers. However, farmers in rural areas in developing countries still find it difficult to access credit to enhance their production [5,6]. The difficulty in raising funds in rural zones will lead to a decline in output, an impact on GDP, and national food security in poor countries [7,8]. Thus, access to rural credit markets is considered to be an important factor in economic development, especially for low-income households [9-11].

Vietnam has been known as a developing country with $70 \%$ population living in rural areas, in which employment in agricultural production accounts for more than $50 \%$ on individual basis. The proportion of households that have their main income from agriculture is nearly $48 \%$ [12]. 
However, household access to credit in Vietnam remains a difficult task because of the nature of the rural credit markets and the lending procedures [13]. Informal and formal markets are observed to commonly exist in rural Vietnam. The supply of formal lenders is quite restricted, because of the formal market imperfection, so the informal credit sources are likely to be dominant in rural areas.

Poor and low-income households are often limited to access formal credit, because they do not have enough collateral, so cannot borrow on the basis of their income $[13,14]$. Nevertheless, so far, there has been surprisingly no review paper reported on access to credit in Vietnam. The previous studies on credit accessibility in Vietnam were just discovered on the regional basis.

Based on the considerations above, the aim of this paper is providing an overall review of important features of rural credit markets as well as determinants of access to rural credit of households in Vietnam and some developing countries. In addition, the socio-economic impacts of credit are also reviewed and then some policy implication focused on Vietnam has been also recommended. Especially, this review analyzes the previous literature from a descriptive viewpoint to summarize and compare the determinants of access to rural credit in Vietnam with other developing countries. By gathering the results of 106 case studies around the world, this analysis is likely to be helpful for decision-makers and researchers to clarify the characteristics of rural markets and the determinants of rural credit accessibility in a particular research site.

The rest of this review is organized, as follows. Section 2 demonstrates the methodology that was used to carry out this review. In Section 3, the overview of access to credit in developing countries are displayed, in which the definitions of the credit access concept, the affecting factors of rural credit market access, as well as the welfare impacts of credit access in some developing nations are summarized. Section 4 is the results of the review of rural credit market features, determinants, and the impacts of access to credit in Vietnam. The main policy implications that are focused on Vietnam and conclusions are presented in Section 5.

\section{Materials and Methods}

This research applied mixed methods that are a comprehensive literature review with secondary data collection and Key Informant Interviews (KIIs). In order to only review quality articles, internationally renowned citation database Scopus, Scholar, and Web of Science were mainly selected. Moreover, some more good papers researched on Vietnam are also reviewed. Keywords, such as "access to rural credit of households/farmers", "rural credit access of households/farmers", "factors affecting access to rural credit", "determinants of rural credit access", "rural credit markets", "credit constraints", "credit participation", etc. were used for searching suitable articles.

For the beginning, a number of 1910 articles were chosen based on the analysis of title, keywords and abstract. These papers were analyzed in detail, and finally only 114 of them were selected. Articles were excluded beyond the scope of the research focusing only on access to rural credit of farming households. Of these, only 15 articles were focused on Vietnam, which has been further processed and analyzed in detail in Section 4.3. The remaining 99 in Scopus, Google Scholar, and Web of Science were focused on the other developing countries. These papers have been summarized as in the framework of Figure 2. They were explored to determine whether the differences of approach of access to rural credit in Vietnam and other developing countries. All of the selected papers are focused on the basis of two main aspects, namely: characteristics of rural credit markets and determinants of rural credit access.

Secondary data of this paper has been collected from yearly official reports of Vietnam Bank for Agriculture and Rural Development (VBARD), Vietnam Bank for Social Policies (VBSP), People Credit Funds (PCFs), as well as some general information from Vietnam Statistical Yearbook of 2016-2017. Some primary data was extracted from KIIs with important representatives of VBARD, VBSP, and PCFs. The Vietnam Central People Credit Funds is now known as the Co-operative Bank of Vietnam that have branches as local People Credit Funds. A total of four key informants were interviewed. The head and the officer of the credit department of VBARD were interviewed regarding bank policies, the credit mechanisms, as well as the implementation of the agricultural loans that are offered by 
the bank. Similarly, one member of board of directors of VBSP and the head of credit department of Co-operative Bank were also interviewed regarding the credit schemes and customer characteristics that they offer to agricultural sectors. The interviews were conversational to meet the objectives of the research.

\section{Overview of Access to Credit in Developing Countries}

\subsection{The Concept of Access to Credit}

There are overlaps in three terms above "rural credit", "agriculture credit", and "microcredit" in financial sectors [15]. Rural credit refers to credit services in rural areas that aim at people at all income level, while agriculture credit is likely to finance agriculture-related activities [16]. Urban agriculture is the part of credit for agriculture in Figure 1 that is not done in rural areas. Urban and peri-urban agriculture can be defined as the growing of plants and the raising of animals within and around cities [17]. Microfinance is the provision of financial services to poor and low-income people, by which they have access to affordable funds to finance their activities to generate income, build assets, smooth consumption, and manage risks. Financial services include credit products (micro-credit), but also savings, money transfers, and insurance [18].

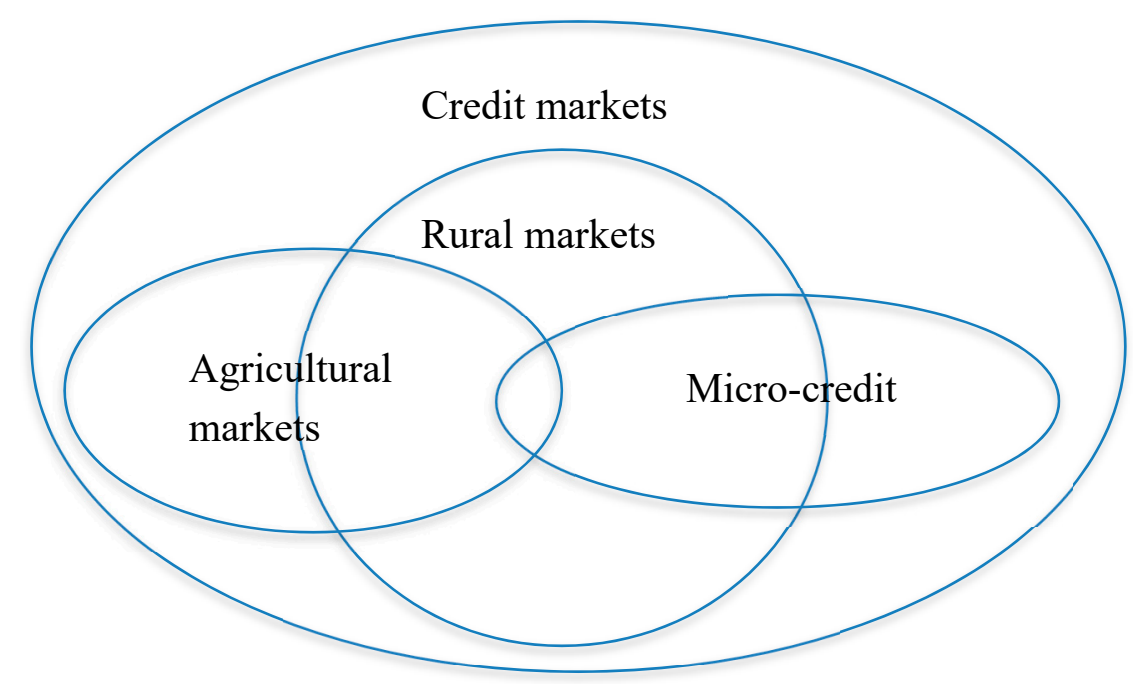

Figure 1. The relationship between financial sectors. Source: Authors' summary.

Access to credit and credit constraints have been defined and measured by the two main methodologies. The indirect way refers to the existence of credit constraints that are based on violations of the life-cycle/permanent income hypothesis, while the direct method uses the concept of demand and supply of credit, i.e., access to credit is measured by the gap between the demand and the supply [19]. However, many empirical proofs on the life-cycle/permanent income hypothesis has been unconvincing [20-23].

It is the second methodology in defining and measuring access to rural credit that are closely related to figure out the determinants of access to credit, which is also presented in the section below. In this method, the borrowers are directly asked about their credit demand and their loan applications, as well as exposure of loan rejections $[19,24,25]$. The data of borrowers' socio-economic characteristics is collected as determinants of credit constraints from the borrowers' view [19]. Regarding credit supply, the lenders are very likely to be constrained by factors on the amount that they can possibly lend. That means credit sources are limited and the suppliers have to choose their potential customers based on the possibility of default $[19,26,27]$. Zeller [28] also indicated that credit rationing is the measurement of access to credit. He also separated the factors that affect demand and the supply of credit. The process begins from whether households decide to take part in the credit markets or not. 
If they choose to borrow, then loan rationing is the amount that they can get from the lenders. In that case, the lenders have rights to partially or fully reject or approve the applied borrowings.

Households' access to rural credit markets can be simply defined as approaching credit services [29]. In a broader way, rural credit means that households have access to specific credit sources among many available ones. Subsequently, access to credit is measured by the largest amount of money that households can borrow [30]. Access to rural credit in some papers is defined as the difficulty of capital accessing by poor households [31,32]. The difference between the two concepts of "access to formal credit" and "participation in formal credit programs" has been shown in some studies [30]. In some cases, these two concepts are interchangeably used. However, the difference between the two is that: participation in credit programs is a matter that farmers can choose to participate in, while access to credit often implies barriers when entering the markets.

\subsection{Determinants of Rural Credit Access}

Credit sources in most nations are generally classified in three categories: formal, semi-formal, and informal credit. The formal one is the source of credit from commercial banks or some credit funds. Informal credit comes from relatives, individual lenders, and associations. The semi-formal sector includes microfinance institution or NGOs, government-supported lending programs that aimed at particular sections of the population, and other non-government projects [19,32]. The informal ones can come form moneylenders, informal credit associations, relatives, or friends.

Factors that influence access to formal credit of farming households in many studies are considered under two main actors as in the framework of Figure 2: borrowers-farmer households/credit demand and lenders-credit suppliers which is presented in the above section as separated demand and supply factors [28]. The demand factors are likely to provide information whether a household is constrained or not, while the supply factors present the amount that the borrowers can gain from the given source of credit [19]. The two aspects of household credit access are considered in most of researches in developing countries.

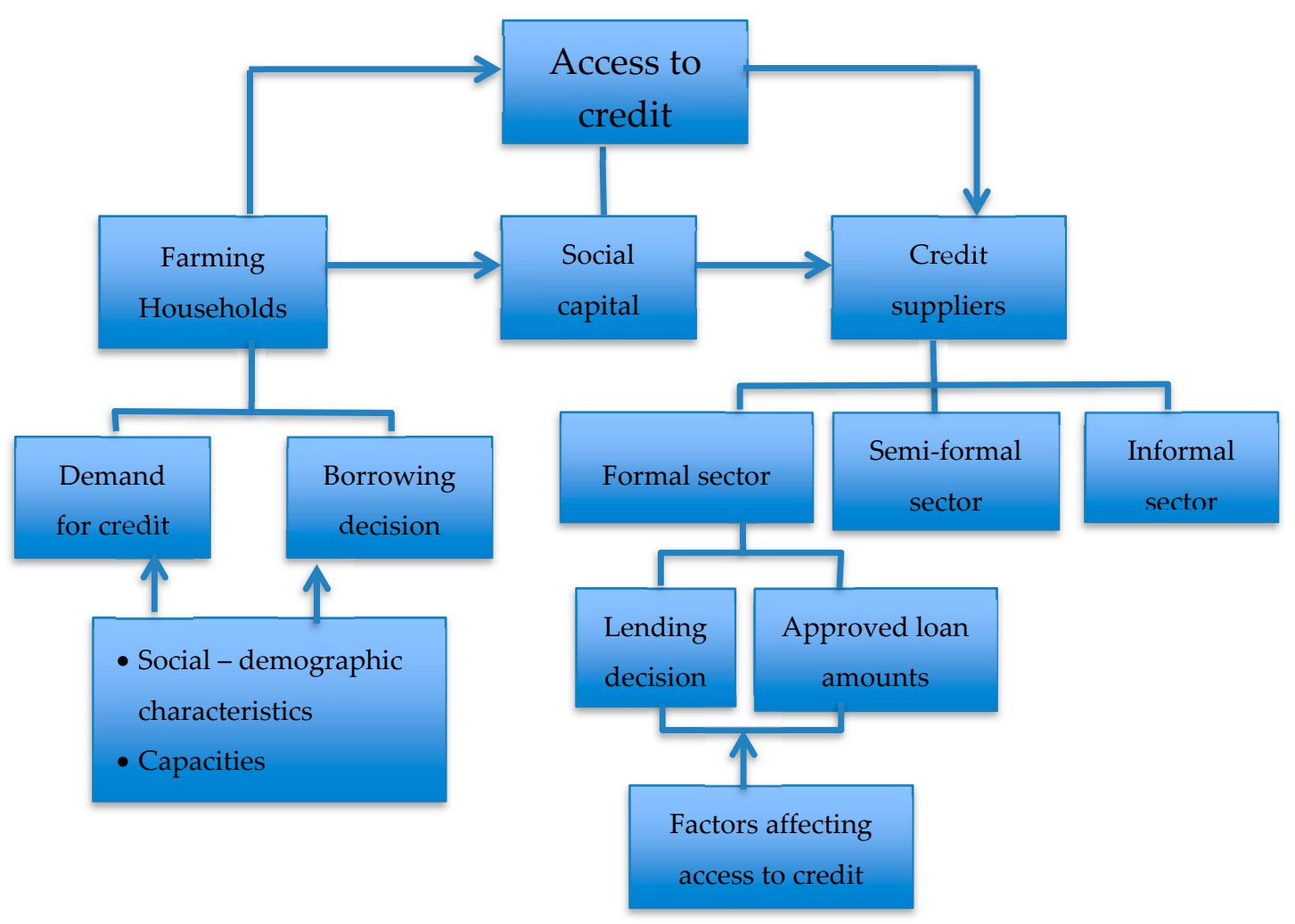

Figure 2. Determinants of access to credit. Source: Authors' summary. 
The determinants of credit access can also be divided into observable and unobservable factors. In Figure 2, the observable ones can be households' socio-economic characteristics as well as factors that affect lenders' decisions, while unobservable factors are social capital/networks that interact both actors in the framework. On the other hand, the semi-formal credit markets shown in Figure 2 that are dominated by NGOs and government-supported credit programs often target particular sections of the population/customers (especially low-income or poor population). Accordingly, the loan processing and loan amounts of semi-formal markets will be much different from the normal financial institutions. Loan procedures of semi-formal lenders are often fixed criteria. Therefore, research on semi-formal lenders' behavior is very difficult to be carried out. In reality, there is little literature on this. That is the reason why the paper does not focus on the determinants of semi-formal lenders' behavior.

Observable factors are socio-economic characteristics and household capacities have been identified in numerous studies in many developing countries.

Age, number of family members, and income all affect access to rural credit [33,34]. Household income, family size, bank distance, loan duration, loan processing, interest rate, and loan size were the main factors affecting households' credit accessibility in the Philippines [34,35]. Interest rate can be found to be a significantly positive factor [36-39]. Education can be seen as one of the most significantly important determinants of credit accessibility in many developing countries [33,35,40-42]. Educated household heads imply having better knowledge, farming skills, as well as information on credit markets. Another factor that is closely related to family size and family income is the dependency ratio. The more dependent members a family has, the higher probability of being poor or the fewer members having regularly income, therefore the household is very likely to be subjected to formal credit constraints $[41,43]$. Group membership seems to increase the probability of household access to agricultural credit, especially in the access to micro-credit program [44]. The factor has been explained to be a guarantee of household loans as association members [28,33]. Hananu indicated that the source of credit being shown to be a significant affecting factor on access to credit is a surprising result [33]. This means that households prefer participating in informal markets to formal ones [43,45-47]. Even in the research of Boucher and Guirkinger, the informal credit markets are likely to be preferred because of risk [48]. However, in other studies, formal and informal credit accessibility are implied to be completely independent and unrelated [32]. Kochar [47] argues that the decision to borrow of a household from formal sources in rural India is influenced by the amount that is gained from informal credit markets. Others figure out the determinants of non-institutional credit contracts, among which interest and loan size are crucial factors [49,50].

Gender has a significant impact on household access [33-35,42,51]. Women are likely to have easier access to rural credit than men, especially micro credit that is provided by NGOs or subsidized by Governments that are targeted towards women. However, in some other papers, male farmers are found to have higher chance of accessing rural credit than female [35]. Experience in agricultural production is also an influential factor, as highlighted in some studies [52,53]. However, in many studies, the area of land is the most important determinant of access to agricultural credit [54,55]. Mohamed, in research in Zanzibar, clarified that household access to information/knowledge of credit sources plays an important role in achieving formal credit [42]. Vaessen also confirmed this factor [56]. Household's wealth status (expenditure per capita) has also proved to have a significantly positive relationship with households' credit access [42,57]. In many studies, residence location or the distance between lender-borrower/distances to credit sources significantly affects credit accessibility [36,57-59].

Chandio et al. have shown that operation holding plays a significant role in farmers credit accessing from formal sources, reflecting declining market participation constraints [36]. Bigger operation holding that is larger farm size requires the more utilization of basic production input, which in turn requires additional funds for purchasing [38,60].

Many studies have found large households to have greater formal accessibility than small households. That means that large households often have more asset possession and collateral security or better land ownership status than smaller ones [36,58,61-63]. Many commercial banks 
are only willing to make lending decision on the basis of collateral, because landholding size is more acceptable as risk management and loan securement for institutional lenders. Collateral is believed to enhance households' repayment possibility [64-66], which is the reason most poor/small households being not able to borrow [13]. In Pakistan, the lack of collateral is the main reason for farmers' inability to reach the rural credit $[62,67,68]$. Credit constraints exist in most nations and it is likely to be worse in developing countries because of shortage of collateral security and imperfect credit markets [26,69]. Besides the factor of collateral shortage, financial institutions in some developing countries are reluctant to finance agricultural sectors because of the risks. Farm household production decisions in developing nations are subject to different restraints, such as technology availability, affordability of inputs, and endowment in land [70,71]; price and production [72,73].

The qualitative factors or unobservable ones, i.e., social capital/social networks have been observed in relationship with famer's credit rationing and credit constraints [74]. The effects of social capital, in general, are detailed in three forms: increasing information availability and reducing the cost; decisions/actions facilitation; and, diminishing opportunistic behavior by member individuals $[75,76]$. In terms of the common interests of social networks in increasing farmers' credit accessibility, many scientists share the same view [77,78]; Bourdieu [79] argues that social networks are a pool of available resources and potential resources. Those resources are connected to form big networks of relationships to achieve common goals. The resources can help the households that have no collateral to achieve loans from bank [80]. Therefore, households with members that work as local officials have a higher probability of accessing to credit because of a good relationship with local financial institutions [43]. In reverse, a large proportion of credit suppliers could seek appropriate customers through the network of the borrowers. On the other hand, social networks have been shown to facilitate rural credit accessibility via the strength of interpersonal relationships [81].

\subsection{The Social and Economic Impacts of Credit Access in Rural Areas}

Undeniably, credit access has a huge socio-economic impact on rural households, such as output/production increasing, improving household income, and poverty reduction $[5,6]$. Guirkinger et al. insisted that credit constrained households are likely to have a lower farm productivity than unconstrained households [7]. Institutional credit access and productivity growth among subsistence food crop farmers in Nigeria are found to have a positive relationship [37]. Most subsistence crop farmers in Nigeria were unable to access credit to improve their production, income, as well as wellbeing. The increase in output and income would lead to a development in the welfare of farmers, thus reducing poverty in the rural economy $[6,39,82]$. Credit is believed to contribute to the improvement of both farm and non-farm income and household livelihood in rural areas [83,84]. However, Diagne and Zeller clarified that the borrowing and net crop incomes of poor households in Malawi have negative correlation [30]. On the other hand, it is off-farm activities that have a close relationship with poverty reduction [83-85]. Formal credit access is shown to have positive impact on household income in the study of Das et al. [86], expanding their livelihood activities and helping them to improve living standard and raise annual income and welfare conditions [87-90]. While many studies find the direct and statistically significant impact of rural credit on output and production, some others believe that output and poverty is indirectly affected by credit access. Ahmad et al. stated that credit just have indirect role in increasing agricultural output through buying various inputs [67]. In other study, the authors figure out it is indirect effects of credit access created through more efficient product and labor that are much more vital than the direct effects. Poverty alleviation does not come from the direct provision of credit to the poor [25], even in reality the poorest are likely to be excluded from the formal lenders because of their bigger risk than the other group of population [91,92]. Das et al. has studied the impact of credit on poverty reduction in terms of formal, semi-formal, and informal credit access [86]. Poverty in this study is measured by three benchmarks: the Planning Commission of India's poverty line, World Bank poverty line, and multidimensional poverty. A significant positive relationship between informal credit access and staying in the World Bank poverty line is found in this 
study, which is because of vulnerable informal borrowers. Microfinance through semi-formal markets have significant effects on reducing poverty when applying the India poverty line. In terms of the multidimensional poverty line, the relationship between formal source access and poverty alleviation is negative and that of the semi-formal and informal ones is positive. Rahman et al. also used the logistic regression model to analyze the impact of agricultural credit on agricultural productivity in Pakistan [62]. The variables' coefficients of credit amount and short-term loan both have a significant positive impact on productivity. Despite a large number of studies being in favor of the significant relationship between credit access and output production, as well as poverty reduction, there are some researches releasing the opposite results about the relationship [93-97].

\section{The Issue of Access to Rural Credit in Vietnam}

\subsection{The Organization of Rural Credit Markets in Vietnam}

Vietnam's rural credit markets include formal, informal, and semi-formal credit (see Table 1). Currently, formal rural credit is provided by most of financial institutions. Commercial banks are increasingly willing to make loans in agriculture and rural areas, mainly the three state-owned banks: Vietnam Bank for Agriculture and Rural Development (VBRAD), Vietnam Bank for Social Policies (VBSP), formerly known as the Bank for the Poor, and the People's Credit Fund. The three organizations control about 70\% rural credit market share. The Bank for Agriculture and Rural Development was established in 1988 and it officially came into operation in December 1990. The bank's network is growing and now it has more than 2000 branches that are spread all over the country. However, due to obsolete operating mechanisms, the state owned bank with a weakness in risk assessment and procedures of loans has resulted in the underdevelopment by itself and has been an ineffective formal credit source.

Table 1. Rural credit markets in Vietnam.

\begin{tabular}{|c|c|c|c|c|c|}
\hline & \multicolumn{3}{|c|}{ Formal Markets } & \multirow{2}{*}{$\begin{array}{l}\text { Semi-Formal } \\
\text { Markets }\end{array}$} & \multirow{2}{*}{ Informal Markets } \\
\hline & VBARD & VBSP & PCFs & & \\
\hline $\begin{array}{c}\text { Targeted } \\
\text { customers }\end{array}$ & $\begin{array}{l}\text { Larger-scale } \\
\text { farmhouse }\end{array}$ & Poor households & $\begin{array}{l}\text { Wide range of } \\
\text { households }\end{array}$ & $\begin{array}{c}\text { Selective } \\
\text { clients, such as } \\
\text { Poor women, } \\
\text { ethnic minority } \\
\text { communities }\end{array}$ & Wide-range of clients \\
\hline $\begin{array}{l}\text { Lending } \\
\text { schemes }\end{array}$ & Individual & $\begin{array}{l}\text { Group-based/ } \\
\text { individual }\end{array}$ & Individual & Individual & Individual \\
\hline Loan size & Large & Small & Small to large & Small & Small to large \\
\hline Interest rate & Low & Low & High & Low & High \\
\hline Loan term & Short-term & Long-term & Short-term & Short-term & $\begin{array}{l}\text { Depending on the } \\
\text { relationship between } \\
\text { lenders and borrowers }\end{array}$ \\
\hline Collateral & $\begin{array}{l}\text { Required land-use } \\
\text { certificate }\end{array}$ & $\begin{array}{l}\text { No collateral for } \\
\text { group-based }\end{array}$ & $\begin{array}{l}\text { No collateral } \\
\text { (depending on } \\
\text { each PCF) }\end{array}$ & No collateral & $\begin{array}{l}\text { Depending on the } \\
\text { relationship between } \\
\text { lenders and borrowers }\end{array}$ \\
\hline
\end{tabular}

The Vietnam Bank for the Poor started to operate in 1996, providing low interest credit through micro-credit programs to the rural poor who were not eligible for personal loans of commercial banks, because of the lack of collateral. By 2002, the Vietnam Bank for Social Policies was established under the Prime Minister's Decision No. 131/2002/QD-TTg dated 4 October 2002 to separate credit for the poor from normal credit by reorganizing the Bank for the Poor. The Bank for Social Policies' activities are mainly indirectly lending the poor, in which the case loan procedure is implemented by the bank, local authorities, and local associations. The borrowers are not required for collateral, but must be 
in the list of poor households of the local commune. The local associations who are involved in loan processing are often Women's Union, Farmers' Association, Veterans Association, and Youth Union. The roles of local organizations are providing guarantees of loans to poor households.

The People's Credit Fund system originated as a pilot program that was supervised by the State Bank in July 1993. It is a saving and credit association that was built based on the Caisse Populaire model, Canada. Credit funds operate mainly in rural areas. The purpose of the funds is to mobilize on-the-spot deposits for local loans as the ways to support community and local development.

The informal credit sector in Vietnam in recent studies has been considered to be an important factor in facilitating household credit access in the formal market. Informal credit in rural Vietnam is mainly from relatives, friends, revolving credit association, such as "ho, hui", or local private lenders with a high interest rate. Local private lenders can be divided in three categories. The first is traditional lenders who often request no collateral. The second one is from the lender with usury. This is basically the same as the first one, but the loan amount is higher and the lenders often demand collateral, i.e., the land use right certificate. The third form of local credit is from small traders, suppliers, or local dealers. The third one has become an important form of informal local credit, with more than $51 \%$ of household credit being granted through this credit channel [98].

In addition to formal and informal credit, there is semi-formal credit in rural Vietnam from micro-credit programs that were funded by international foundations and non-governmental organizations (NGO). The beneficiaries of the semi-formal sector are often the poor women, ethnic minority communities, and often those who could not access the formal credit. On the other hand, a number of funds come from social associations, such as Women's Union, Veterans Association, and Farmers' Union, in which Women's Union has succeeded in meeting its members' credit demand.

The organization of rural credit markets in Vietnam has been comprehensively summarized in Table 1.

\subsection{Characteristics of Rural Credit Markets in Vietnam}

\subsubsection{Constrained Credit Market Participation with Heavy Subsidization}

Constrained credit market participation results from both credit suppliers and demanders as households. Following the decision of the State Bank of Vietnam No. 546/2002/QD-NHNN, commercial banks are free to negotiate the interest rates with their customers, while the State Bank still controls the ceiling rate at a maximum level, not exceeding $150 \%$ of the base rate. State Bank's controlling the ceiling rate has influenced the performance of commercial banks, forcing them to have more rigorous customer selection [99]. The agricultural sector is considered to be so risky due to complicated weather happenings, unpredictable diseases, and pests [100-102]. This is especially true in developing countries, such as Vietnam, because science and technology skills are still weak, depending on natural resources and shortage of funds $[103,104]$. In addition, it is the incomplete demand-oriented policies of agricultural products, fragmented cultivation $[105,106]$, and the inappropriate price policy between the central government versus the local/rural levels [107] that make lending in agriculture so risky. Therefore, commercial banks postpone taking part in the agriculture credit markets. On the other hand, in Vietnam, there is little risk sharing between the banks and Government. The Bank for Agriculture and Rural Development, as one of the largest state-owned commercial banks in Vietnam, is oriented as one of the leading banks in agricultural lending from Decree 53./HDBT of Vietnam Council of Ministers. However, as a commercial bank for profit, VBARD has a risk appraisal process and loan approval on the basis of mortgage and income for paying debts. However, the income of the farmers is quite low and they do not have enough collateral to get big borrowings from commercial banks for production expansion. Vietnam Bank for Social Policies (VBSP) is willing to lend without collateral, but approved amounts are quite limited.

The Vietnam Bank for Social Policies provides loans at a subsidized interest rate and at the total lending amounts set by the government. Loan capital through the social policy bank is allocated to 
the provinces and cities and then allocated to the local farmers. The beneficiaries of the bank are the poor people in multi-dimensional poverty line or the customers of subsidized lending programs. In reality, many households who need to raise funds for production are not in the list of the poor of local authorities. The fact is very common in big cities or urbanized provinces, in which the number of the poor increasingly decreases. Due to the low rate of VBSP, the demand for credit is strong. Consequently, the demand will exceed the supply and applicant screening will become more difficult. In this case, basically, people with political influence or that have a close relationship with authorities or non-poor can easily obtain cheap funds [108]. Braverman and Guasch [109] also indicated that, in rural credit markets of developing countries, wealthier farmers find it easier to obtain credit loans than small farmers who are likely to be rationed out of the credit markets.

\subsubsection{Government Intervention}

A high level of government intervention characterizes the Vietnamese rural credit market [110]. Government intervention includes regulations of the interest rate of the lending and policies related debt repayment in the event of drought or natural disasters [111-113]. In developing countries, Governments can regarded as a leader and regulator of effective rural credit markets [114], while Claessens [9] points out that interventions of Governments originate costly and risky access to credit of households. In Vietnam, the roles of Government intervention are known via State-owned Bank of Vietnam's activities (Central bank-SBV). The SBV' decrees mainly are basically theoretical by requesting commercial banks to broaden their agricultural loans. However, SBV hardly makes moves to share risks with the banks.

\subsubsection{Segmented Markets}

The rural credit market in Vietnam is segmented because of lending purpose differences. It the fact that the choices of credit sources of households are distinguishing based on their purpose [115]. The formal markets focus on credit for production, while the informal ones are likely to be diverse. The different segmentation of rural credit markets is also observed to serve different needs, in which the formal sectors direct their lending in production [116]. Rural credit markets with the feature of fragmentation and segmentation have also been indicated with different types of loan and credit sources [99]. In Nepal, Yadav contrasted the differences of segmented rural financial market [117], such as the distinguishing lending purposes and diversified interest rate.

\subsection{Factors Affecting Rural Credit Access and the Socio-Economic Impacts of Credit Access in Vietnam}

Table 2, below, shows the previous articles on rural Vietnam, which are often carried in many provinces with different climate, geography, and households' socio-economic characteristics. The table categorizes the affecting factors of credit access into the demand and supply factors (see Table 2). In this context, the former can be defined as determinants of access to rural credit and the latter as determinants of the borrowed amount. The concept has been well described in Section 3.2. Authors in each paper use not only different names of determinants but also different number of factors (see Table 2).

Similar to Vietnam studies, foreign researches also use different factors and indicators when studying the factors that affect rural credit access of farming households, which are also mentioned in Section 3.2 "Determinants of rural credit access". Essentially, comparisons between them will enhance the goal and focus of the study. There is no consensus in the names of factors used. They are different in each country or between studies among a nation. The determinants of probability of access to credit and credit amounts are often grouped in four categories: household socio-demographic characteristics, household capacities, credit factors, and social capital. Both foreign and Vietnam studies (in Table 2) use basic socio-demographic characteristics that are: age, gender, education, household size, farming experience, dependency ratio, and distance to financial institutions. However, in Vietnam papers, the authors have stated the factor "ethnic" and "urbanized commune", which are different from foreign researches $[13,14,118]$. 
Table 2. Determinants of rural access to credit in Vietnam.

\begin{tabular}{|c|c|c|c|c|c|c|c|}
\hline \multirow[b]{2}{*}{ Author(s) } & \multirow[b]{2}{*}{ Year } & \multirow[b]{2}{*}{ Title of Paper } & \multirow[b]{2}{*}{ Journal } & \multicolumn{2}{|c|}{ Determinants of Access to credit } & \multirow[b]{2}{*}{ Models } & \multirow[b]{2}{*}{ Places of Survey } \\
\hline & & & & $\begin{array}{l}\text { Determinants of Access to Rural } \\
\text { Credit/Credit Constraints }\end{array}$ & Determinants of Borrowed Amount & & \\
\hline $\begin{array}{l}\text { Luan D.X. et al. } \\
\text { [119] }\end{array}$ & 2016 & $\begin{array}{l}\text { Does credit access affect } \\
\text { household income } \\
\text { homogeneously across } \\
\text { different groups of credit } \\
\text { recipients? Evidence from } \\
\text { rural Vietnam }\end{array}$ & $\begin{array}{l}\text { Journal of rural } \\
\text { studies }\end{array}$ & $\begin{array}{l}\text { Number of people known who could be } \\
\text { asked for help (social capital); Number of } \\
\text { contacts with agricultural extension (social } \\
\text { capital); Age of households heads; Total } \\
\text { value of savings; Households experience of } \\
\text { types of shock }\end{array}$ & Not mentioned & Probit model & $\begin{array}{l}12 \text { provinces in the } \\
\text { River Delta, Northern } \\
\text { Mountains, the } \\
\text { Central Coast and the } \\
\text { Mekong River Delta }\end{array}$ \\
\hline Khoi P.D. et al. [13] & 2013 & $\begin{array}{l}\text { Formal and informal rural } \\
\text { credit in the Mekong river } \\
\text { delta of Vietnam: } \\
\text { interaction and } \\
\text { accessibility }\end{array}$ & $\begin{array}{l}\text { Journal of Asian } \\
\text { Economics }\end{array}$ & $\begin{array}{l}\text { Age; marital status; ethnicity; government } \\
\text { employees; member of credit group; poor } \\
\text { certificate; income levels; sources of main } \\
\text { income; direct road access to village; } \\
\text { urbanized commune and the informal } \\
\text { amount }\end{array}$ & $\begin{array}{l}\text { From informal sources: age, education, } \\
\text { landownership, savings, income levels, } \\
\text { purposes of informal loan, informal interest } \\
\text { rate, duration of informal loan, direct road } \\
\text { access to village, urbanized commune } \\
\text { From formal sources: education, household } \\
\text { head's occupation, agricultural land area, } \\
\text { household expenditure, subsidized interest, } \\
\text { purpose of formal loan, urbanized commune }\end{array}$ & $\begin{array}{l}\text { Heckman two-step } \\
\text { model }\end{array}$ & $\begin{array}{l}15 \text { villages of } 13 \\
\text { communes in Mekong } \\
\text { River Delta Vietnam }\end{array}$ \\
\hline $\begin{array}{l}\text { Dinh Q.H. et al. } \\
\text { [118] }\end{array}$ & 2012 & $\begin{array}{l}\text { Does connections matter? } \\
\text { Individual social capital } \\
\text { and credit constraints in } \\
\text { Vietnam }\end{array}$ & $\begin{array}{l}\text { European Journal } \\
\text { of Development } \\
\text { Research }\end{array}$ & $\begin{array}{l}\text { Income and past income, district } \\
\text { dummy / location } \\
\text { Bonding link: strong ties to persons of } \\
\text { higher social standing } \\
\text { Past credit } \\
\text { Ethnic }\end{array}$ & Not mentioned & $\begin{array}{l}\text { Zero-Inflated } \\
\text { Negative Binomial } \\
\text { model }\end{array}$ & Son La province \\
\hline Duy V.Q. et al. [14] & 2012 & $\begin{array}{l}\text { Determinants of } \\
\text { household access to } \\
\text { formal credit in the rural } \\
\text { areas of the Mekong delta, } \\
\text { Vietnam }\end{array}$ & $\begin{array}{l}\text { African and Asian } \\
\text { Studies }\end{array}$ & $\begin{array}{l}\text { Individual access to credit: age, value of } \\
\text { building, ethnicity, family size, distance to } \\
\text { the market centre, social capital } \\
\text { Group-based access to rural credit: marital } \\
\text { status, education, total land size, distance } \\
\text { to the market centre }\end{array}$ & $\begin{array}{l}\text { Individual: dependency ratio, family size, } \\
\text { having job in community, household head } \\
\text { gender, total land size, ethnicity, social } \\
\text { capital } \\
\text { Group-based: dependency ratio, having a } \\
\text { community work, total land size }\end{array}$ & $\begin{array}{l}\text { Heckman and } \\
\text { Double hurdle } \\
\text { model }\end{array}$ & $\begin{array}{l}\text { T Three provinces in } \\
\text { the Mekong Delta: } \\
\text { Can Tho, Soc Trang, } \\
\text { Tra Vinh }\end{array}$ \\
\hline $\begin{array}{l}\text { Barslund M. et al. } \\
\text { [116] }\end{array}$ & 2008 & $\begin{array}{l}\text { Formal and informal rural } \\
\text { credit in four provinces of } \\
\text { Vietnam }\end{array}$ & $\begin{array}{l}\text { Journal of } \\
\text { Development } \\
\text { Studies }\end{array}$ & $\begin{array}{l}\text { Credit demand: } \\
\text { Land size (depending on each province), } \\
\text { district dummy/location, connection, the } \\
\text { number of adults, the age of household } \\
\text { head, distance from village center } \\
\text { Credit rationing: the age of household } \\
\text { head, gender, the number of adults, } \\
\text { livestock holdings, connections }\end{array}$ & $\begin{array}{l}\text { Credit demand: } \\
\text { Land size (depending on each province), } \\
\text { assets and livestock holdings }\end{array}$ & $\begin{array}{l}\text { Probit model, } \\
\text { lognormal model, } \\
\text { Heckman's } \\
\text { selection model }\end{array}$ & $\begin{array}{l}\text { Long An in Mekong } \\
\text { Delta, Quang Nam in } \\
\text { Central Highlands, } \\
\text { Phu Tho in North } \\
\text { Western Highlands, } \\
\text { Ha Tay in the Red } \\
\text { River Delta }\end{array}$ \\
\hline $\begin{array}{l}\text { Bao Duong, P. et al. } \\
\text { [115] }\end{array}$ & 2002 & $\begin{array}{l}\text { Rural development } \\
\text { finance in Vietnam: a } \\
\text { microeconomic analysis of } \\
\text { household surveys }\end{array}$ & $\begin{array}{l}\text { World } \\
\text { development }\end{array}$ & $\begin{array}{l}\text { Reputation (social capital), dependency } \\
\text { ratio, amount of credit applied to the bank }\end{array}$ & $\begin{array}{l}\text { Farm size, total production value of } \\
\text { livestock, dependency ratio }\end{array}$ & $\begin{array}{l}\text { Tobit and Probit } \\
\text { model }\end{array}$ & $\begin{array}{l}\text { Ninh Binh (Red River } \\
\text { Delta), Quang Ngai } \\
\text { (South of Central Part) } \\
\text { An Giang (Mekong } \\
\text { River Delta) }\end{array}$ \\
\hline
\end{tabular}

Source: Authors' summary. 
Regarding households capacities, foreign authors often indicate total land size or just farm size and household income. Land size is regarded as collateral is one of the main constraints on household credit accessibility, especially small households $[36,58,61-63,67,68]$. However, two Vietnamese studies have specified the factor "livestock holdings/value of livestock" besides household land size and household income. In Bao Duong's research, which was carried on in four provinces in Vietnam, i.e., Ha Tay, Long An, Phu Tho, and Quang Nam [115], assets and livestock holdings are shown to affect credit amounts instead of credit accessibility, in which feed expenditure as a proxy for the size of livestock holdings. The factor "livestock" has been also mentioned in the research of Barslund in four Vietnam provinces. In this study, livestock is defined as the value of livestock that is measured by the cash amount at the point of selling in case of approaching due date [116]. The factor "livestock" has been little mentioned in the other researches in other developing countries.

Credit factors, such as: loan duration, loan processing, interest rate, loan size or applied loans, credit history or past credit, and sources of credit, are less mentioned in Vietnam when compared to the foreign studies. Past credit has been shown in the paper of Dinh Q.H. et al. [118]. Only Khoi P.D. et al. has deeply analyzed the effect of credit sources on access to rural credit [13]. In detail, the study dealt with the relationship between formal and informal credit sources, in which the amount that is obtained from informal markets has a positive relationship with accessibility of the formal micro-credit market. On the other hand, the paper also defined the determinants of borrowed amounts from formal sources and informal sources separately.

In spite of the little credit factors mentioned, all of the Vietnam studies (in Table 2) have indicated the importance of social capital in access to rural credit in Vietnam. Do Xuan Luan indicated social capital as one important factors that affect credit accessibility [119], in which social capital is known as the numbers of helpers and number of contacts with agricultural extension in the last 12 months. Social capital/social networks in the research of Khoi P.D. et al. [13] is known as household participation in the credit group. Barslund M. et al. has named social capital or social network as households' acquaintances in existing credit institutions. On the other hand, social capital in the survey by Bao Duong P. et al. is defined as reputation and social status [115]. Reputation reflects the households' economic position as well as their prestige in a village, which is determined by the head of a committee of a hamlet and is classified into five categories: top group, upper middle, middle, lower middle, and bottom group. Similarly, a household's social status is the position of the head of household. Dinh Q.H. et al. [118] has clarified social networks through the bonding link that means strong ties to persons of higher social standing.

In terms of socio-economic impacts of credit access, a small number of Vietnam studies have been taken into account in this relationship, similar to literature of other developing countries. In his research, Do Xuan Luan [119] also mentioned the welfare impact of credit, as represented by total household income. Total income and per capita income of credit recipients are shown to be higher than non-recipients. However, credit is not found to have a significant impact on farm-income among different categorized credit recipients, which is due to farming shock. Among credit recipients with the largest loan volume, credit has a significant negative impact on farm income [119]. Regarding recipients categorized by ethnicity, the results also show credit access have the positive relationship with Kinh majority's total off-farm income and negative sign for Kind' farm income. In contrast to the Kind majority, credit has no significant effects on total income, per capita income, as well as non-farm income of ethnic minorities [119]. The same findings regarding the Ethnic Majority and Minorities are also mentioned in the study of Tu et al. [120]. Hong Son et al. [121] believed that, with the increase in the income of borrower, credit access also has positive impacts on poverty reduction in general. Duy used frontier analysis and quintile regression and found a positive effect of institution and non-institution credit on farm output and production efficiency [122]. In Duy's other study on rice, technical efficiency and rice yields were positively influenced by both formal and informal credit access [123]. Productive efficiency of crop farms in Vietnam, including technical and scale efficiency of rice and maize crop, affected by access to credit, extension services, and milling machines 
are demonstrated by Linh et al. [124]. Some others just indicated the role of non-farm activities in reducing poverty $[125,126]$. On the other hand, some Vietnam authors figure out that credit access, especially formal and semi-formal access, is not really efficient in the reduction of poverty and rural growth, i.e., subsidized credit for the poor. Although Do Xuan Luan shown the positive relationship between total income and credit access of households in general, he also gave evidence of the negative impact of credit on total income and non-farm income among the poorest borrowers [119], which is consistent with literature in some developing countries. On the other study of Khoi et al., the wealthier households are less constrained than the poorer among target poor households of a subsidized credit program [13]. The evidence of Dufhues et al., in Northern Vietnam, supports this finding [127]. Saint-Macary and Zellerm in a study of Northern Vietnam, also showed inefficient subsidized credit that led to credit rationing and misallocation due to inappropriate agriculture polices has limited impact on poverty alleviation and rural growth [128].

\section{Conclusions and Managerial Implications}

In line with the objective of reviewing and classifying some studies, several issues that relate to agriculture credit markets in rural areas have been discussed. Rural credit markets in some developing countries often include both formal and informal markets. The two markets can complement each other. Many socio-economic factors, such as: age, family size, household income, education, gender, and size of landholdings, has an impact on farmers' credit accessibility. Besides the observable factors, social capital is also seen as the invisible one affecting households' access to credit. In the paper, an overview of Vietnam rural credit markets and its characteristics of limited market participation, government intervention, and segmentation have been clearly indicated. Some different determinants of Vietnam rural credit market access from foreign studies are highlighted as ethnic, urbanized commune, and value of livestock/livestock holdings. The factor of social capital factor is found in most Vietnam studies. The socio-economic impacts of credit access are considered in both foreign and Vietnam rural. Although positive relationship among credit access, output production, productive efficiency, and total household income are found in most papers; credit also has positively significant impacts on only non-farm income. The poor farmers with their main income from agricultural activities are likely to be excluded from formal markets. This is due to vulnerable farming activities and inefficient in agricultural policies. Accordingly, some studies have shown that credit access, especially formal access, is not efficient in reducing poverty.

The results of this study have a number of implications, which can be helpful to decision makers, especially in developing countries as well as in Vietnam. Credit policies should be adaptable to different household groups.

For households - the main solutions by some researchers often refer to expanding the lending network of financial institutions through local socio-political associations as guarantors and borrowers that gathered in groups $[13,129,130]$. Participation in these groups significantly increases the probability of access to formal credit programs, reducing the transaction costs, since asymmetric information effectively drops [131].

For financial institutions-they need to change their mind-set about target clients. Commercial banks now just focus on "big customers" rather than agricultural-sector customers. Banks' lending decisions are very likely to be focused on specific groups, not general [132]. Banks should allocate capital to agricultural sectors, enhance loan procedures, and reduce lending costs.

For policy-makers-government intervention in rural credit markets should be determined to ensure market competitiveness. Subsidized credit is likely to be increasingly ineffective in fast-growing economies. On-time loans with convenient procedure and low transaction cost should meet farmers' demand. Therefore, government policies on credit need to ensure sustainability and development in the long run, not only focusing on the subsidized loans in short-term. Moreover, the government should have policies to expand the activities of microfinance institutions, reaching the poor class, especially in rural areas of big cities. 
This study is subject to certain limitations and it also provides insights for further research. The study is limited to an exploration of the status of rural financial market of Vietnam. Therefore, future research is recommended on comparative studies of the markets in other developing countries in terms of characteristics and components of the markets. On the other hand, appropriate lending models of each lender to households can be considered in the future, which characterize the rural markets. Reviews of methods that are used to analyze the impact of agriculture output and production efficiency remain uncovered in this research. Accordingly, techniques for impact analysis and current agricultural credit policies' influence can be studied further.

Author Contributions: P.L. and L.T.T.: Conceptualization, methodology, supervision; T.N.L.: writing-original draft preparation, writing-review and editing; L.V.C. and H.T.L.: writing-review and editing.

Funding: This research was funded by National Economics University, Hanoi, Vietnam.

Conflicts of Interest: The authors declare no conflict of interest.

\section{References}

1. Soubbotina, T.P.; Sheram, K. Beyond Economic Growth: Meeting the Challenges of Global Development; World Bank Publications: Washington, DC, USA, 2000.

2. Aleem, I. Imperfect information, screening, and the costs of informal lending: a study of a rural credit market in Pakistan. World Bank Econ. Rev. 1990, 4, 329-349. [CrossRef]

3. Saqib, S.; Kuwornu, J.K.M.; Panezia, S.; Ali, U. Factors determining subsistence farmers' access to agricultural credit in flood-prone areas of Pakistan. Kasetsart J. Soc. Sci. 2018, 39, 262-268. [CrossRef]

4. Deelstra, T.; Girardet, H. Urban agriculture and sustainable cities. In Growing Cities, Growing Food, Urban Agriculture on the Policy Agenda; Bakker, N., Dubbeling, M., Gündel, S., Sabel-Koshella, U., de Zeeuw, H., Eds.; Zentralstelle für Ernährung und Landwirtschaft (ZEL): Feldafing, Germany, 2000; pp. 43-66.

5. Yadav, P.; Sharma, A.K. Agriculture credit in developing economies: A review of relevant literature. Int. J. Econ. Financ. 2015, 7, 219. [CrossRef]

6. Malik, S.J.; Nazli, H. Rural poverty and credit use: Evidence from Pakistan. Pak. Dev. Rev. 1999, 38, 699-716. [CrossRef]

7. Guirkinger, C.; Boucher, S.R. Credit constraints and productivity in Peruvian agriculture. Agric. Econ. 2008, 39, 295-308. [CrossRef]

8. Godfray, H.C.J.; Beddington, J.R.; Crute, I.R.; Haddad, L.; Lawrence, D.; Muir, J.F.; Pretty, J.; Robinson, S.; Thomas, S.M.; Toulmin, C. Food security: The challenge of feeding 9 billion people. Science 2010, 327, 812-818. [CrossRef]

9. Claessens, S. Access to financial services: A review of the issues and public policy objectives. World Bank Res. Obs. 2006, 21, 207-240. [CrossRef]

10. Ellis, F. The determinants of rural livelihood diversification in developing countries. J. Agric. Econ. 2000, 51, 289-302. [CrossRef]

11. Tsai, K.S. Imperfect Substitutes: The Local Political Economy of Informal Finance and Microfinance in Rural China and India. World Dev. 2004, 32, 1487-1507. [CrossRef]

12. GSO. Statistic Year Book; GSO: San Ramon, CA, USA, 2017.

13. Khoi, P.D.; Gan, C.; Nartea, G.V.; Cohen, D.A. Formal and informal rural credit in the Mekong River Delta of Vietnam: Interaction and accessibility. J. Asian Econ. 2013, 26, 1-13. [CrossRef]

14. Duy, V.Q.; D'Haese, M.; Lemba, J.; D'Haese, L. Determinants of household access to formal credit in the rural areas of the Mekong Delta, Vietnam. Afr. Asian Stud. 2012, 11, 261-287. [CrossRef]

15. CGAP. Donor Brief No.15; CGAP: Washington, DC, USA, 2003.

16. Le Thi Minh, C. An Analysis of Access to Credit by Animal Producing Households in Hai Duong Province, Vietnam; Université de Liège Gembloux Agro-Bio Tech: Gembloux, Belgique, 2014.

17. FAO. FAO's Role in Urban Agriculture; FAO: Rome, Italy, 2019.

18. CGAP. A Guide to Regulation and Supervision of Microfinance; CGAP: Washington, DC, USA, 2012.

19. Diagne, A.; Zeller, M.; Sharma, M. Empirical Measurements of Households' Access to Credit and Credit Constraints in Developing Countries: Methodological Issues and Evidence; Citeseer: State College, PA, USA, 2000. 
20. Zeldes, S.P. Consumption and liquidity constraints: An empirical investigation. J. Political Econ. 1989, 97, 305-346. [CrossRef]

21. Carroll, C.D. Buffer Stock Saving and the Permanent Income Hypothesis; Board of Governors of the Federal Reserve System (US): Washington, DC, USA, 1991.

22. Deaton, A. Saving and Liquidity Constraints; National Bureau of Economic Research: Cambridge, MA, USA, 1989.

23. Browning, M.; Lusardi, A. Household saving: Micro theories and micro facts. J. Econ. Lit. 1996, 34, 1797-1855.

24. Boucher, S.R.; Guirkinger, C.; Trivelli, C. Direct elicitation of credit constraints: Conceptual and practical issues with an application to Peruvian agriculture. Econ. Dev. Cult. Chang. 2009, 57, 609-640. [CrossRef]

25. Beck, T.; Demirgüç-Kunt, A.; Honohan, P. Access to financial services: Measurement, impact, and policies. World Bank Res. Obs. 2009, 24, 119-145. [CrossRef]

26. Stiglitz, J.E.; Weiss, A. Credit rationing in markets with imperfect information. Am. Econ. Rev. 1981, 71, 393-410.

27. Thomas, L.C. A survey of credit and behavioural scoring: Forecasting financial risk of lending to consumers. Int. J. Forecast. 2000, 16, 149-172. [CrossRef]

28. Zeller, M. Determinants of credit rationing: A study of informal lenders and formal credit groups in Madagascar. World Dev. 1994, 22, 1895-1907. [CrossRef]

29. Zeller, M.; Ahmed, A.U.; Babu, S.C.; Broca, S.; Diagne, A.; Sharma, M.P. Rural Finance Policies for Food Security of the Poor: Methodologies for a Multicountry Research Project; International Food Policy Research Institute: Washington, DC, USA, 1996.

30. Diagne, A.; Zeller, M. Access to Credit and Its Impact on Welfare in Malawi; International Food Policy Research Institute: Washington, DC, USA, 2001; Volume 116.

31. Hinson, R.E. Banking the poor: The role of mobiles. J. Financ. Serv. Mark. 2011, 15, 320-333. [CrossRef]

32. Pham, T.T.T.; Lensink, R. Lending policies of informal, formal and semiformal lenders: Evidence from Vietnam. Econ. Trans. 2007, 15, 181-209. [CrossRef]

33. Hananu, B.; Abdul-Hanan, A.; Zakaria, H. Factors influencing agricultural credit demand in Northern Ghana. Afr. J. Agric. Res. 2015, 10, 645-652.

34. Gray, A. Credit Accessibility of Small-Scale Farmers and Fisherfolk in the Philippines; Lincoln University: Oxford, PA, USA, 2006.

35. Kosgey, Y.K.K. Agricultural credit access by grain growers in Uasin-Gishu County, Kenya. IOSR 2013, 2, 36-52. [CrossRef]

36. Chandio, A.A.; Jiang, Y. Determinants of Credit Constraints: Evidence from Sindh, Pakistan. Emerg. Mark. Financ. Trade 2018, 54, 3401-3410. [CrossRef]

37. Ugwumba, C.; Omojola, J. Credit access and productivity growth among subsistence food crop farmers in Ikole Local Government Area of Ekiti State, Nigeria. ARPN J. Agric. Biol. Sci. 2013, 8, 351-356.

38. Duniya, K.; Adinah, I. Probit analysis of cotton farmers' accessibility to credit in northern guinea savannah of Nigeria. Asian J. Agric. Ext. Econ. Sociol. 2015, 4, 296-301. [CrossRef]

39. Bashir, M.K.; Azeem, M.M. Agricultural credit in Pakistan: Constraints and options. Pak. J. Life Soc. Sci. 2008, 6, 47-49.

40. Mohieldin, M.S.; Wright, P.W. Formal and informal credit markets in Egypt. Econ. Dev. Cult. Chang. 2000, 48, 657-670. [CrossRef]

41. Okurut, F.N.; Schoombee, A.; Van der Berg, S. Credit Demand and Credit Rationing in the Informal Financial Sector in Uganda 1. South Afr. J. Econ. 2005, 73, 482-497. [CrossRef]

42. Mohamed, K. Access to Formal and Quasi-Formal Credit by Smallholder Farmers and Artisanal Fishermen: A Case Study of Zanzibar; Mkuki na Nyota Publishers: Dar es Salaam, Tanzania, 2003; ISBN 9987-686-75-3.

43. Li, X.; Gan, C.; Hu, B. Accessibility to microcredit by Chinese rural households. J. Asian Econ. 2011, 22, 235-246. [CrossRef]

44. Evans, T.G.; Adams, A.M.; Mohammed, R.; Norris, A.H. Demystifying nonparticipation in microcredit: A population-based analysis. World Dev. 1999, 27, 419-430. [CrossRef]

45. Guirkinger, C. Understanding the Coexistence of Formal and Informal Credit Markets in Piura, Peru. World Dev. 2008, 36, 1436-1452. [CrossRef]

46. Conning, J.; Udry, C. Rural financial markets in developing countries. Handb. Agric. Econ. 2007, 3, $2857-2908$. 
47. Kochar, A. An empirical investigation of rationing constraints in rural credit markets in India. J. Dev. Econ. 1997, 53, 339-371. [CrossRef]

48. Boucher, S.; Guirkinger, C. Risk, wealth, and sectoral choice in rural credit markets. Am. J. Agric. Econ. 2007, 89,991-1004. [CrossRef]

49. Siamwalla, A.; Pinthong, C.; Poapongsakorn, N.; Satsanguan, P.; Nettayarak, P.; Mingmaneenakin, W.; Tubpun, Y. The Thai rural credit system: Public subsidies, private information, and segmented markets. World Bank Econ. Rev. 1990, 4, 271-295. [CrossRef]

50. Nagarajan, G.; Meyer, R.L.; Hushak, L.J. Demand for Agricultural Loans: A Theoretical and Econometric Analysis of the Philippine Credit Market/La Demande de Prêts Agricoles: Une Analyse Théorique Et Économique Du Marché De Crédit Aux Philippines. Sav. Dev. 1998, 22, 349-363.

51. Sebatta, C.; Wamulume, M.; Mwansakilwa, C. Determinants of smallholder farmers' access to agricultural finance in Zambia. J. Agric. Sci. 2014, 6, 63. [CrossRef]

52. Nguyen, T.D.; Le, H.T. Enhancing formal credit accessibility of pig production households in Thai Binh province, Vietnam. Int. J. Econ. Commer. Manag. 2015, 3, 1-15.

53. Yehuala, S. Determinants of Smallholder Farmers Access to Formal Credit: The Case of Metema Woreda, North Gondar, Ethiopia; Haramaya University: Dire Dawa, Ethiopia, 2008.

54. Saleem, A.; Jan, F.A.; Khattak, R.M.; Quraishi, M.I. Impact of Farm and Farmers Characteristics On Repayment of Agriculture Credit. Abasyn Univ. J. Soc. Sci. 2011, 4, $23-35$.

55. Field, E.; Torero, M. Do Property Titles Increase Credit Access Among the Urban Poor? Evidence from a Nationwide Titling Program; Working Paper; Department of Economics, Harvard University: Cambridge, MA, USA, 2006.

56. Vaessen, J. Accessibility of rural credit in northern nicaragua: the importance of networks of information and recommendation/accessibilité du crédit rural dans le nord du nicaragua: l'importance des réseaux d'information et de recommandation. Sav. Dev. 2001, 25, 5-32.

57. Okurut, F.N. Access to Credit by the Poor in South Africa: Evidence from Household Survey Data 1995 and 2000; University of Botswana: Gaborone, Botswana, 2006.

58. Bigsten, A.; Collier, P.; Dercon, S.; Fafchamps, M.; Gauthier, B.; Gunning, J.W.; Oduro, A.; Oostendorp, R.; Patillo, C.; Söderbom, M. Credit constraints in manufacturing enterprises in Africa. J. Afr. Econ. 2003, 12, 104-125. [CrossRef]

59. Atieno, R. Formal and Informal Institutions' Lending Policies and Access to Credit by Small-Scale Enterprises in Kenya: An Empirical Assessment; African Economic Research Consortium: Nairobi, Kenya, 2001.

60. Oboh, V.U.; Ekpebu, I.D. Determinants of formal agricultural credit allocation to the farm sector by arable crop farmers in Benue State, Nigeria. Afr. J. Agric. Res. 2011, 6, 181-185.

61. Heltberg, R. Rural market imperfections and the farm size-Productivity relationship: Evidence from Pakistan. World Dev. 1998, 26, 1807-1826. [CrossRef]

62. Rahman, S.; Hussain, A.; Taqi, M. Impact of agricultural credit on agricultural productivity in Pakistan: An empirical analysis. Int. J. Adv. Res. Manag. Soc. Sci. 2014, 3, 125-139.

63. Swaminathan, M. Segmentation, collateral undervaluation, and the rate of interest in agrarian credit markets: Some evidence from two villages in South India. Camb. J. Econ. 1991, 15, 161-178.

64. Hussain, A.; Thapa, G.B. Smallholders' access to agricultural credit in Pakistan. Food Secur. 2012, 4, 73-85. [CrossRef]

65. Saqib, S.E.; Ahmad, M.M.; Panezai, S. Landholding size and farmers' access to credit and its utilisation in Pakistan. Dev. Pract. 2016, 26, 1060-1071. [CrossRef]

66. Zeller, M.; Diagne, A.; Mataya, C. Market access by smallholder farmers in Malawi: Implications for technology adoption, agricultural productivity and crop income. Agric. Econ. 1998, 19, 219-229. [CrossRef]

67. Ahmad, N. Impact of Institutional Credit on Agricultural Output. Pak. Dev. Rev. 2011, 42, 469-485.

68. Khandker, S.; Faruqee, R.R. The Impact of Farm Credit in Pakistan; The World Bank: Washington, DC, USA, 1999.

69. Xinkai, Z.; Gang, L. Dual Financial Institution and Farmers' Choice on Consumer Credit Behavior: The Explanation and Analysis of ROSCA. Econ. Res. J. 2009, 2, 005.

70. Croppenstedt, A.; Demeke, M.; Meschi, M.M. Technology adoption in the presence of constraints: The case of fertilizer demand in Ethiopia. Rev. Dev. Econ. 2003, 7, 58-70. [CrossRef]

71. De Janvry, A.; Fafchamps, M.; Sadoulet, E. Peasant household behaviour with missing markets: Some paradoxes explained. Econ. J. 1991, 101, 1400-1417. [CrossRef] 
72. Di Falco, S.; Chavas, J.P.; Smale, M. Farmer management of production risk on degraded lands: The role of wheat variety diversity in the Tigray region, Ethiopia. Agric. Econ. 2007, 36, 147-156. [CrossRef]

73. Di Falco, S.; Chavas, J.-P. On crop biodiversity, risk exposure, and food security in the highlands of Ethiopia. Am. J. Agric. Econ. 2009, 91, 599-611. [CrossRef]

74. Van Bastelaer, T. Does social capital facilitate the poor's access to credit. In Understanding and Measuring Social Capital: A Multidisciplinary Tool for Practitioners; The World Bank: Washington, DC, USA, 2002; pp. 237-264.

75. Yokoyama, S.; Ali, A.K. Social capital and farmer welfare in Malaysia. Jpn. Agric. Res. Q. JARQ 2009, 43, 323-328. [CrossRef]

76. Fukuyama, F. Social capital, civil society and development. Third World Q. 2001, 22, 7-20. [CrossRef]

77. Grootaert, C.; Oh, G.T.; Swamy, A. Social capital, household welfare and poverty in Burkina Faso. J. Afr. Econ. 2002, 11, 4-38. [CrossRef]

78. Okten, C.; Osili, U.O. Social networks and credit access in Indonesia. World Dev. 2004, 32, 1225-1246. [CrossRef]

79. Bourdieu, P. The forms of capital.(1986). Cult. Theory Anthol. 2011, 1, 81-93.

80. Chloupkova, J.; Bjønskov, C. Counting in social capital when easing agricultural credit constraints. J. Microfinance/ESR Rev. 2002, 4, 3.

81. Van Bastelaer, T. Imperfect Information, Social Capital and the Poor's Access to Credit. 1999. Available online: https: / / papers.ssrn.com/sol3 / papers.cfm?abstract_id=260058 (accessed on 5 March 2019).

82. Olagunju, F. Impact of credit use on resource productivity of sweet potatoes farmers in Osun-State, Nigeria. J. Soc. Sci. 2007, 14, 177-178. [CrossRef]

83. Walle, d.v.D.; Cratty, D. Is the Emerging Nonfarm Market Economy the Route out of Poverty in Vietnam? The World Bank: Washington, DC, USA, 2003.

84. Lanjouw, J.O.; Lanjouw, P. The rural non-farm sector: Issues and evidence from developing countries. Agric. Econ. 2001, 26, 1-23. [CrossRef]

85. Imai, K.S.; Gaiha, R.; Kang, W. Vulnerability and poverty dynamics in Vietnam. Appl. Econ. 2011, 43, 3603-3618. [CrossRef]

86. Das, T. Does credit access lead to expansion of income and multidimensional poverty? A study of rural Assam. Int. J. Soc. Econ. 2018. [CrossRef]

87. Khandker, S.R. Microfinance and poverty: Evidence using panel data from Bangladesh. World Bank Econ. Rev. 2005, 19, 263-286. [CrossRef]

88. Copestake, J.; Dawson, P.; Fanning, J.P.; McKay, A.; Wright-Revolledo, K. Monitoring the diversity of the poverty outreach and impact of microfinance: A comparison of methods using data from Peru. Dev. Policy Rev. 2005, 23, 703-723. [CrossRef]

89. Bashir, M.K.; Mehmood, Y.; Hassan, S. Impact of agricultural credit on productivity of wheat crop: Evidence from Lahore, Punjab, Pakistan. Pak. J. Agric. Sci. 2010, 47, 405-409.

90. Ekwere, G.; Edem, I. Evaluation of agricultural credit facility in agricultural production and rural development. Glob. J. Hum. Soc. Sci. Res. 2014.

91. Hermes, N.; Lensink, R. Microfinance: Its impact, outreach, and sustainability. World Dev. 2011, 39, 875-881. [CrossRef]

92. Amin, S.; Rai, A.S.; Topa, G. Does microcredit reach the poor and vulnerable? Evidence from northern Bangladesh. J. Dev. Econ. 2003, 70, 59-82. [CrossRef]

93. Bateman, M.; Chang, H.-J. The microfinance illusion. SSRN Electron. J. 2009. [CrossRef]

94. Niño-Zarazúa, M. The Impact of Credit on Income Poverty in Urban Mexico. An Endogeneity-Corrected Estimation; University of Sheffield: Sheffield, UK, 2007.

95. Morduch, J.; Haley, B. Analysis of the Effects of Microfinance on Poverty Reduction; NYU Wagner: New York, NY, USA, 2002.

96. Khaki, A.R.; Sangmi, M.-u.-D. Does access to finance alleviate poverty? A case study of SGSY beneficiaries in Kashmir Valley. Int. J. Soc. Econ. 2017, 44, 1032-1045. [CrossRef]

97. Imai, K.; Arun, T. Does Microfinance Reduce Poverty in India; University of Manchester: Manchester, UK, 2008.

98. Putzeys, R. Micro Finance in Vietnam: Three Case Studies. Available online: https:/ / www.findevgateway. org/library/microfinance-vietnam-three-case-studies (accessed on 5 March 2019).

99. Hof, K.; Stiglitz, J. Imperfect Inform ationand Rural Credit Markets: Puzzlesand Policy Perspectives. World Bank Econ. 1990, 4, 235-250. [CrossRef] 
100. Thornton, P.K.; van de Steeg, J.; Notenbaert, A.; Herrero, M. The impacts of climate change on livestock and livestock systems in developing countries: A review of what we know and what we need to know. Agric. Syst. 2009, 101, 113-127. [CrossRef]

101. Nardone, A.; Ronchi, B.; Lacetera, N.; Ranieri, M.S.; Bernabucci, U. Effects of climate changes on animal production and sustainability of livestock systems. Livest. Sci. 2010, 130, 57-69. [CrossRef]

102. Georgopoulou, E.; Mirasgedis, S.; Sarafidis, Y.; Vitaliotou, M.; Lalas, D.P.; Theloudis, I.; Giannoulaki, K.D.; Dimopoulos, D.; Zavras, V. Climate change impacts and adaptation options for the Greek agriculture in 2021-2050: A monetary assessment. Clim. Risk Manag. 2017, 16, 164-182. [CrossRef]

103. Tanaka, T.; Camerer, C.F.; Nguyen, Q. Risk and time preferences: Linking experimental and household survey data from Vietnam. Am. Econ. Rev. 2010, 100, 557-571. [CrossRef]

104. Neil Adger, W. Social Vulnerability to Climate Change and Extremes in Coastal Vietnam. World Dev. 1999, 27, 249-269. [CrossRef]

105. Marsh, S.P.; MacAulay, T.G.; Hung, P.V. Agricultural Development and Land Policy in Vietnam; Australian Centre for International Agricultural Research (ACIAR): Canberra, Australia, 2006; 272p.

106. Erickson, D.L.; Lovell, S.T.; Méndez, V.E. Identifying, quantifying and classifying agricultural opportunities for land use planning. Landsc. Urban Plan. 2013, 118, 29-39. [CrossRef]

107. White, C. Agricultural planning, pricing policy and co-operatives in Vietnam. World Dev. 1985, 13, 97-114. [CrossRef]

108. Waheed, S. Does rural micro credit improve well-being of borrowers in the Punjab (Pakistan)? Pak. Econ. Soc. Rev. 2009, 47, 31-47.

109. Braverman, A.; Guasch, J.L. Rural credit markets and institutions in developing countries: Lessons for policy analysis from practice and modern theory. World Dev. 1986, 14, 1253-1267. [CrossRef]

110. McCarty, A. Microfinance in Vietnam: A Survey of Schemes and Issues; Department for International Development (DFID) and the State Bank of Vietnam (SBVN): Hanoi, Vietnam, 2001.

111. Nelson, R.; Howden, M.; Smith, M.S. Using adaptive governance to rethink the way science supports Australian drought policy. Environ. Sci. Policy 2008, 11, 588-601. [CrossRef]

112. Freebairn, J.W. Drought assistance policy. Aust. J. Agric. Econ. 1983, 27, 185-199. [CrossRef]

113. Clarke, D.J.; Grenham, D. Microinsurance and natural disasters: Challenges and options. Environ. Sci. Policy 2013, 27, S89-S98. [CrossRef]

114. Bhatt, V.V.; Mundial, B. Financial Innovation and Credit Market Development; The World Bank: Washington, DC, USA, 1989.

115. Bao Duong, P.; Izumida, Y. Rural Development Finance in Vietnam: A Microeconometric Analysis of Household Surveys. World Dev. 2002, 30, 319-335. [CrossRef]

116. Barslund, M.; Tarp, F. Formal and informal rural credit in four provinces of Vietnam. J. Dev. Stud. 2008, 44, 485-503. [CrossRef]

117. Yadav, S.; Otsuka, K.; David, C.C. Segmentation in rural financial markets: The case of Nepal. World Dev. 1992, 20, 423-436. [CrossRef]

118. Dinh, Q.H.; Dufhues, T.B.; Buchenrieder, G. Do connections matter? Individual social capital and credit constraints in Vietnam. Eur. J. Dev. Res. 2012, 24, 337-358. [CrossRef]

119. Luan, D.X.; Bauer, S. Does credit access affect household income homogeneously across different groups of credit recipients? Evidence from rural Vietnam. J. Rural Stud. 2016, 47, 186-203. [CrossRef]

120. Tu, T.T.T.; Ha, N.P.; Yen, T.T.H. Socio-economic impact of rural credit in northern Vietnam: Does it differ between clients belonging to the ethnic majority and the minorities? Asian Soc. Sci. 2015, 11, 159.

121. Duong, H.A.; Nghiem, H.S. Effects of microfinance on poverty reduction in Vietnam: A pseudo-panel data analysis. J. Account. Financ. Econ. 2014, 4, 58-67.

122. Duy, V.Q. The Role of Access to Credit in Rice Production Efficiency of Rural Households in the Mekong Delta Vietnam; Center for Asian Studies: Kaunas, Lithuania, 2012.

123. Duy, V.Q.; Neuberger, D.; Suwanaporn, C. Access to credit and rice production efficiency of rural households in the Mekong delta. J. Account. Bus. Res. 2012, 3, 33-48. [CrossRef]

124. Linh, T.T.; Nanseki, T.; Chomei, Y. Productive efficiency of crop farms in Viet Nam: A DEA with a smooth bootstrap application. J. Agric. Sci. 2015, 7, 37. [CrossRef]

125. Hoang, T.X.; Pham, C.S.; Ulubaşoğlu, M.A. Non-farm activity, household expenditure, and poverty reduction in rural Vietnam: 2002-2008. World Dev. 2014, 64, 554-568. [CrossRef] 
126. Tran, T.Q. Nonfarm employment and household income among ethnic minorities in Vietnam. Econ. Res. Ekon. Istraživanja 2015, 28, 703-716. [CrossRef]

127. Dufhues, T.; Buchenrieder, G. Outreach of Credit Institutes and Households' Access Constraints to Formal Credit in Northern Vietnam; Universität Hohenheim: Stuttgart, Germany, 2005.

128. Saint-Macary, C.; Zeller, M. Rural Credit Policy in the Mountains of Northern Vietnam: Sustainability, Outreach and Impact; Universität Hohenheim: Stuttgart, Germany, 2011.

129. Ghatak, M.; Guinnane, T.W. The economics of lending with joint liability: Theory and practice1. J. Dev. Econ. 1999, 60, 195-228. [CrossRef]

130. Karlan, D.S.; Goldberg, N. Impact Evaluation for Microfinance: Review of Methodological Issues; The World Bank: Washington, DC, USA, 2007.

131. Quach, M.H. Access to Finance and Poverty Reduction: An Application to Rural Vietnam; University of Birmingham: Birmingham, UK, 2005.

132. Rahji, M.; Fakayode, S. A multinomial logit analysis of agricultural credit rationing by commercial banks in Nigeria. Int. Res. J. Financ. Econ. 2009, 24, 97-103.

(C) 2019 by the authors. Licensee MDPI, Basel, Switzerland. This article is an open access article distributed under the terms and conditions of the Creative Commons Attribution (CC BY) license (http://creativecommons.org/licenses/by/4.0/). 